\title{
METODA VIDEO-FEEDBACK INTERVENTION TO PROMOTE POSITIVE PARENTING AND SENSITIVE DISCIPLINE (VIPP-SD) W PRACY TERAPEUTYCZNEJ Z RODZICAMI DZIECI Z GRUPY RYZYKA ROZWOJOWEGO
}

\begin{abstract}
Kopeć Danuta, Kubiak Hanna, Metoda Video-feedback Intervention to promote Positive Parenting and Sensitive Discipline (VIPP-SD) w pracy terapeutycznej z rodzicami dzieci z grupy ryzyka rozwojowego [The Method of Video-feedback Intervention to Promote Positive Parenting and Sensitive Discipline (VIPP-SD) in Therapeutic Work with Parents of Children in the Development Risk Group]. Studia Edukacyjne nr 49, 2018, Poznań 2018, pp. 315-333. Adam Mickiewicz University Press. ISSN 12336688. DOI: $10.14746 /$ se.2018.49.19
\end{abstract}

Video-feedback Intervention to promote Positive Parenting and Sensitive Discipline (VIPP-SD) is a therapeutic intervention based on video-feedback which aims to support positive parenting and sensitive parental discipline. It is a part of evidence-based therapeutic interventions, which means that the effectiveness of the training has been confirmed in rigorously planned and carried out studies of both the general population and various clinical groups. The theoretical framework for VIPP-SD is attachment theory and coercion theory. The basic principle of intervention is referring to family resources in the therapeutic work, primarily in situations in which the correct course of a child's development can be disturbed by both biological and environmental factors. The article presents the aspects of the application of VIPP-SD in the following clinical groups: families with children at risk of improper development, families in which the functioning of parents creates the development risk for children, and the family environment as a risk factor for children's development.

Key words: Video-feedback Intervention to promote Positive Parenting and Sensitive Discipline (VIPP-SD), attachment theory, parental sensitivity, coercion theory, development risk of children, mental disorders of children, mental disorders of parents 


\section{Wprowadzenie}

Angielski termin Video-feedback Intervention to promote Positive Parenting and Sensitive Discipline (VIPP-SD) ${ }^{1} \mathrm{w}$ dosłownym tłumaczeniu oznacza interwencję terapeutyczną wykorzystującą wideofeedback, której celem jest wspieranie pozytywnego rodzicielstwa oraz wrażliwej rodzicielskiej dyscypliny. Metoda VIPP-SD mieści się zatem w obszarze „psychoterapii niemowlę/dziecko-rodzic"2, a jej ramą teoretyczną jest teoria przywiązania (attachment theory $)^{3}$ Johna Bowlby' ego ${ }^{4}$ i Mary Ainsworth ${ }^{5}$, uznana przez badaczy za jedną z tych teorii naukowych, które w największym stopniu wpłynęły na psychologię rozwojową i kliniczną dziecka ${ }^{6}$. Dzięki Bowlby'emu, Ainsworth oraz kontynuatorom badań nad więzią emocjonalną ${ }^{7}$ teza o kluczowym zna-

${ }^{1} \mathrm{~W}$ tekście jako nazwa metody będzie stosowany akronim VIPP-SD, obecny w literaturze przedmiotu (por. F. Juffer., M.J. Bakermans-Kranenburg, M. van IJzendoorn, Promoting positive parenting. An attachment - based intervention, New York - London 2008; F. Juffer, M.J. Bakermans-Kranenburg, M. van IJzendoorn, Manual VIPP-SD. Video-feedback Intervention to promote Positive parenting and Sensitive Discipline, Leiden 2015.

${ }^{2}$ Por. G. Kmita, Psychoterapia i niemowlęta, [w:] Psychoterapia. Problemy pacjentów, red. L. Grzesiuk, H. Suszek, Warszawa 2011, s. 340-399; tenże, Co analiza w triadzie matka-ojciec-dziecko wnosi do rozumienia problemów dzieci zagrożonych zaburzeniami rozwoju i ich rodziców, [w:] W relacji. Studia z psychologii klinicznej dziecka 30 lat później, red. M. Święcicka, Warszawa 2018, s. 69-88.

${ }_{3}^{3}$ Teoria przywiązania wyrosła, co prawda, z psychoanalizy, ale również czerpała z innych teorii i dziedzin nauki, takich jak: etologia, cybernetyka, psychologia rozwojowa, psychologia poznawcza, teorie procesów poznawczych, neurofizjologia, teoria systemów kontroli (M. Stawicka, Autodestruktywność dziecięca w świetle teorii przywiązania, Poznań 2008, s. 48; G. Kmita, Psychoterapia i niemowlęta, s. 340). Zdaniem polskich badaczy zajmujących się teorią przywiązania, pozytywną konsekwencją tej różnorodności jest jej wysoki walor eksplanacyjny, a w związku z tym duża użyteczność, zaś konsekwencją negatywną - trudności, z którymi musi się mierzyć badacz, związane z ustaleniem definicji przywiązania oraz jednoczesnym ujmowaniem wszystkich jego wymiarów (E. Pisula, Autyzm i przywiazanie. Studia nad interakcjami dzieci z autyzmem i ich matek, Gdańsk 2003, s. 35-36).

${ }^{4}$ J. Bowlby, Attachment and loss, Vol. 1 - Attachment, New York 1969; tenże, Attachment and loss, Vol. 2 - Separation, New York 1973; tenże, Attachment and loss, Vol. 2 - Loss: Sadness and depression, New York 1980.

${ }^{5}$ M.D.S. Ainsworth, Infancy in Uganda. Infant care and the growth of love, Oxford 1967; M.D.S.Ainsworth, S. Bell, D.D.J. Stayton, Individual differences in Strange Situation behaviour of one-year-olds, [w:] The origins of human relations, red. H.R. Schaffer, London 1971, s. 17-56; M.D.S.Ainsworth i in., Patterns of attachment. A psychological study of the Strange Situtation, Kraków 1978.

${ }^{6}$ W. Dixon, Twenty studies that revolutionized child psychology, wyd. 2, New York 2016; G. Kmita, Co analiza w triadzie matka-ojciec-dziecko wnosi, s. 69-88.

7 Por. M. Main, J. Solomon, Procedures of Identifying Infants as Disorganized/Disoriented during the Anisworth Strange Situation, [w:] Attachment in the preschool years: theory, research, and intervention, red. M.T. Greenberg, D. Cichetti, M. Cummings, Chicago 1990, s. 121-161; J. Cassidy, Emotion regulation: influences of attachment relationships, Monographs of the Society for Research in Child Development, red. N. Fox, 1994, 59(2-3), s. 228-250; A. Sroufe, Psychopathology as outcome of development, Development and Psychopathology, 1997, 9, s. 251-268. 
czeniu więzi emocjonalnej dla rozwoju psychiki ludzkiej nie budzi już żadnych zastrzeżeń - wręcz przeciwnie. Zdaniem Kmity,

wciąż inspiruje do dalszych poszukiwań badawczych, a zwłaszcza w kierunku wyjaśniania odmiennych trajektorii rozwojowych w obliczu różnych czynników ryzyka - tak biologicznych, jak i środowiskowych ${ }^{8}$.

Najnowsze prace teoretyczne i empiryczne nad relacją przywiązania upatrują w niej swoisty tygiel rozwojowy, który, co bardzo ważne, pełni również rolę pierwotnego regulatora i organizatora zjawisk emocjonalnych, poznawczych, fizjologicznych, neuropsychologicznych9. Jak twierdzi Siegel,

[u]mysł osoby wyłania się z aktywności mózgu, którego strukturę i funkcję bezpośrednio kształtuje doświadczenie interpersonalne ${ }^{10}$. Na poziomie umysłu przywiązanie ustanawia relację interpersonalną, która pomaga niedojrzałemu mózgowi w wykorzystaniu dojrzałych funkcji mózgu rodzica do organizacji własnych procesów ${ }^{11}$.

Należy jednak pamiętać, że tylko relacja o cechach ufnej relacji będzie dla osoby korzystna z perspektywy prawidłowej trajektorii rozwojowej. Zdaniem Bowlby'ego, ufna relacja ${ }^{12}$ powinna spełniać dwie funkcje:

- po pierwsze: bezpiecznej przystani, która jest źródłem komfortu emocjonalnego i daje poczucie bezpieczeństwa ${ }^{13}$;

- po drugie: bezpiecznej bazy dla eksploracji świata zewnętrznego, tzn. bazy do „podążania za własną wrodzoną ciekawością i pragnieniem zdobywania sprawności, kiedy wydaje się ono bezpieczne"14.

Zdaniem Kmity, terapie $\mathrm{z}$ udziałem niemowląt/małych dzieci i ich rodziców można podzielić, z uwzględnieniem kryterium celu, któremu terapia służy oraz kryterium, które uwzględnia sposób i zakres zaangażowania niemowlęcia ${ }^{15}$. Mając na uwadze kryterium celu można podzielić metody terapeutyczne na dwie grupy. Celem pierwszej jest zmiana repre-

${ }^{8}$ G. Kmita, Co analiza w triadzie matka-ojciec-dziecko wnosi, s. 73.

9 Por. D. Górska, M. Stawicka, Mentalizacja w kontekście przywiazania, [w:] Mentalizacja z perspektywy rozwojowej i klinicznej, red. L. Cierpiałkowska, D. Górska, Poznań 2016, s. 42-64.

${ }^{10}$ D. Siegel, Rozwój umystu. Jak stajemy się tym, kim jesteśmy, Kraków 2009, s. 1.

${ }_{11}$ Tamże, s. 61.

12 Obecna w teorii przywiązania klasyfikacja wzorców przywiązania opisuje zawsze specyfikę relacji przywiązaniowej, a nie osobę. Relacja jest kategorią psychologiczną, którą można sprowadzić do wzajemnego istnienia w psychicznej przestrzeni (M. Zalewska, Dziecko i jego rodzice w kontakcie z psychologiem klinicznym, [w:] Problematyka kontaktu w diagnozie i terapii dzieci, red. M. Święcicka, M. Zalewska, Warszawa 2005, s. 10; por. G. Kmita, Psychoterapia i niemowlęta, s. 344-346).

${ }_{13}$ B. Powel i in., Krag ufności. Interwencja wzmacniająca przywiązanie we wczesnych relacjach rodzic-dziecko, Kraków 2015, s. 58.

14 Tamże, s. 57.

${ }^{15}$ G. Kmita, Psychoterapia i niemowlęta, s. 346-347. 
zentacji dziecka w umyśle matki/ojca poprzez pracę nad reprezentacją (np. terapia niemowlę-rodzic Fraiberg, terapia matka-niemowlę w ujęciu grupy genewskiej, tj. Cramera i Palacio-Espasa). Celem drugiej grupy jest zmiana zachowań interakcyjnych partnerów (np. doradztwo interakcyjne Susan McDonough ${ }^{16}$. Uwzględniając kryterium sposobu i zakresu zaangażowania niemowlęcia, można również wyodrębnić dwie grupy. Grupę pierwszą stanowią metody terapeutyczne, w których udział dziecka sprowadza się do zwiększenia motywacji rodziców lub jest katalizatorem dla eksplorowania związków pomiędzy przeszłością a teraźniejszością, relacjami z osobami znaczącymi z własnego dzieciństwa a relacjami z własnym dzieckiem ${ }^{17}$. Na grupę drugą składają się terapie kierowane przez dziecko (infant-led therapies) (np. terapia: „zobacz, zaczekaj, zaciekaw się"18, opracowana przez Cohen, Muir oraz Lojkaskę) $)^{19}$. Odnosząc powyższe kryteria do metody VIPP-SD, można stwierdzić, że jest to interwencja mająca na celu, po pierwsze: zmianę zachowań interakcyjnych partnerów oraz po drugie: jest to terapia kierowana przez dziecko.

\section{Przegląd badań empirycznych dokumentujących skuteczność interwencji terapeutycznych VIPP oraz VIPP-SD}

Należy pamiętać, że procesowi pracy nad metodą VIPP/VIPP-SD oraz jej implementacji towarzyszyły badania empiryczne. Polegały one na przeglądzie oraz metaanalizie $\mathbf{7 0}$ przeprowadzonych i udokumentowanych badań oraz 88 efektów interwencji terapeutycznych ${ }^{20}$. Były to badania oraz interwencje terapeutyczne bazujące na teorii przywiązania. Na podstawie przeprowadzonej przez siebie metaanalizy, badacze doszli do wniosku, że dokonane interwencje miały wpływ na:

- podniesienie poziomu wrażliwości rodzicielskiej: 7,636 rodzin;

- przywiązanie, poprzez zmianę modelu więzi: 1,503 rodziny ${ }^{21}$.

16 Tamże, s. 346.

17 Tamże, s. 347.

${ }^{18}$ W języku angielskim Watch, Wait and Wonder (tamże).

19 Za: tamże, s. 340-399; Porównanie wybranych terapii wykorzystujących analizę interakcji rodzice-dziecko można znaleźć w pracy G. Kmity (tamże, s. 354).

${ }^{20}$ F. Juffer, M.J. Bakermans-Kranenburg, M. van IJzendoorn, Promoting positive parenting, s. 37-57; C. Werner, VIPP-SD Training Course - niepublikowane materiały szkoleniowe z kursu VIPP-SD, 25-28.10, Bydgoszcz 2015, s. 6.

${ }^{21}$ F. Juffer, M.J., Bakermans-Kranenburg, M., van IJzendoorn, Promoting positive parenting, s. 73 . 
Badacze zainspirowani powyższymi wynikami badań, mając na uwadze poziom wrażliwości rodzicielskiej oraz styl przywiązania mierzyli efektywność 77 (53/24) interwencji terapeutycznych w RTC (ang. randomized control trial) z uwzględnieniem wielkości efektu $d$ Cohena. Badacze stwierdzili, że interwencja terapeutyczna ma istotny wpływ na:

- wrażliwość rodzicielską ( $0,33 d$ Cohena ) - istotność na średnim poziomie;

- przywiązanie $\left(0,2 d\right.$ Cohena) - istotność na niskim poziomie ${ }^{22}$.

Wyniki przeprowadzonych badań pokazały, że interwencje terapeutyczne mają istotnie statystycznie większy wpływ na wrażliwość rodzicielską ${ }^{23}$. Juffer, van IJzendoorn, Bakermans-Kranenburg postawili sobie kolejne pytanie dotyczące liczby interwencji istotnych dla kształtowania wrażliwości rodzicielskiej mierzonej wielkością efektu $d$ Cohena. Okazało się, że dla wykształcenia wrażliwości rodzicielskiej większy wpływ mają interwencje krótkoterminowe:

- do 5 sesji: 0,42 d Cohena;

- do 16 sesji: 0,38 $d$ Cohena;

- więcej niż 16: 0,21 $d$ Cohena.

Wyniki przeprowadzonych badań pokazały, że na wrażliwość rodzicielską istotnie statystycznie większy wpływ mają interwencje krótkotermino$w^{24}$. Egzemplifikacją tego wniosku jest zalecenie ograniczonej liczby interwencji terapeutycznych: MNIEJ ZNACZY WIĘCEJ - ang. Less is more $e^{25}$.

W swojej metaanalizie badacze zwrócili uwage również na interwencje terapeutyczne wspierające bezpieczny styl przywiązania. Stwierdzono, że tylko interwencje terapeutyczne, podczas których wspierana jest wrażliwość rodzicielska $\mathrm{w}$ porównaniu $\mathrm{z}$ innymi sprzyjają pojawieniu się bezpiecznego stylu przywiązania:

- interwencje terapeutyczne wspierające wrażliwość wychowawczą: 0,39d Cohena;

- pozostałe interwencje terapeutyczne: 0,06 $d$ Cohena $^{26}$.

Badacze podjęli również próbę metaanalizy interwencji terapeutycznych, w których uczestniczyły dzieci ze zdezorganizowanym stylem przywiązania

${ }^{22}$ Tamże, s. 195-215; F. Juffer, M. van IJzendoorn, M.J. Bakermans-Kranenburg, Less is more. Meta-analyses of sensitivity and attachment interventions in early childhood, Psychological Bulletin, 2003, 129, s. 195-215.

${ }^{23}$ F. Juffer, M., van IJzendoorn, M.J. Bakermans-Kranenburg, Less is more, s. 195-215; F. Juffer, M.J. Bakermans-Kranenburg, M. van IJzendoorn, Promoting positive parenting, s. 72-74.

${ }^{24}$ F. Juffer, M. van IJzendoorn, M.J. Bakermans-Kranenburg, Less is more, s. 195-215.

${ }_{25}$ Tamże; F. Juffer, M.J. Bakermans-Kranenburg, M. van IJzendoorn, Promoting positive parenting, s. 59-74.

${ }^{26}$ C. Werner, VIPP-SD Training Course, s. 7. 
15 przedstawionych badań ${ }^{27}$. W metaanalizie zwrócono uwagę na dwie kategorie interwencji terapeutycznych, mających kształtować wrażliwość rodzicielską oraz innych. Badacze doszli do wniosku, że tylko interwencje mające na celu wykształcenie wrażliwości rodzicielskiej wpływają na zmniejszenie liczby dzieci ze zdezorganizowanym stylem przywiązania:

- interwencje wpierające wrażliwość rodzicielską: -0,26 d Cohena;

- inne interwencje: $0,08 d$ Cohena $^{28}$.

Na podstawie wyników przeprowadzonych badań można wysnuć następujące wnioski, mające swoje odzwierciedlenie w metodzie VIPP-SD:

- łatwiej wspierać wrażliwość rodzicielską niż bezpieczny styl przywiązania;

- „mniej znaczy więcej”, co przekłada się na ograniczoną liczbę interwencji terapeutycznych,

- interwencje bazujące na wrażliwości rodzicielskiej skutkują większą efektywnością we wspieraniu bezpiecznego stylu przywiązania i redukowaniu zdezorganizowanego stylu przywiązania ${ }^{29}$.

Przeprowadzono również badania dotyczące długotrwałych efektów VIPP. Zostały one przeprowadzone na próbie dzieci objętych stosowaniem metody VIPP po 40 miesiącach od zakończenia interwencji. Okazało się, że mniej dzieci objętych interwencją VIPP-SD przejawiało kliniczne problemy w zachowaniu ${ }^{30}$.

\section{Podstawowe założenia VIPP-SD i algorytm interwencji terapeutycznej}

W metodzie VIPP-SD można wyróżnić jej dwie części składowe, widoczne w nazwie, które można również uznać za egzemplifikację rozwoju metody:

- VIPP (Video-feedback Intervention to promote Positve Parenting);

- SD (Sensitive Discipline), które kolejno zostaną scharakteryzowane z uwzględnieniem ich odniesienia teoretycznego i celu.

${ }^{27}$ F. Juffer, M.J. Bakermans-Kranenburg, M. van IJzendoorn, Disorganized infant attachment and preventive interventions: A review and meta-analysis, Infant Mental Health Journal, 2005, 26, s. 191-216; F. Juffer, M.J. Bakermans-Kranenburg, M. van IJzendoorn, Promoting positive parenting, s. 59-75.

28 C. Werner, VIPP-SD Training Course, s. 8.

29 Tamże, s. 8.

${ }^{30} \mathrm{~V}$. Klein i in., Effects of attachment-based interventions on maternal sensitivity and infant attachment: Differential susceptibility of highly reactive infants, Journal of Family Psychology, 2006, 20, s. 266-274. 
VIPP stanowi terapię krótkoterminową, a jej celem jest wspieranie rodziców i ich rodzicielską wrażliwość. Była ona formą krótkoterminowej interwencji, która została zaproponowana przez naukowców z Uniwersytetu w Leiden w Holandii: Femmie Juffer, Marinusa H. van IJzendoorna, Mariana J. Bakermans-Kranenburga ${ }^{31}$ prawie 30 lat temu. Ramą teoretyczną VIPP jest teoria przywiązania (attachment theory) ${ }^{32}$, a przede wszystkim sposób rozumienia wrażliwości rodzicielskiej ${ }^{33}$.

VIPP jako metoda terapii odwołująca się do teorii więzi spełnia następujące warunki:

- po pierwsze: zapewnia emocjonalną i fizyczną dostępność rodzica;

- po drugie: skupia się na wrażliwej responsywności rodziców w odpowiedzi na sygnały wysyłane przez dziecko;

- po trzecie: umożliwia rodzicom przyjęcie postawy podążającej za potrzebami i aktywnością dziecka, nieintruzywnej, która umożliwi dziecku swobodne poznanie otoczenia;

- po czwarte: rola terapeuty sprowadza się do pełnienia funkcji bezpiecznej bazy dla diady $\mathrm{w}$ procesie przepracowania trudności relacyjnych; terapeuta jest zatem $\mathrm{w}$ pewnym stopniu modelem dla rodzica $\mathrm{w}$ jego byciu $\mathrm{z}$ dzieckiem ${ }^{34}$.

Przedstawione powyżej elementy przekładają się na zasady postępowania w ramach metody VIPP, to znaczy na:

- celową obserwację zachowań dziecka i jego szczegółowy opis;

- świadomy, responsywny sposób reagowania na zachowania dziecka ${ }^{35}$.

VIPP jest traktowany jako samodzielna metoda terapeutyczna stosowana $\mathrm{w}$ pracy z dziećmi do pierwszego roku życia i ich rodzicami/opiekunami ${ }^{36}$.

VIPP-SD jest również terapią krótkoterminową, której cel polega na wspieraniu rodziców dzieci od pierwszego do czwartego roku życia oraz ich

${ }^{31}$ M.E. Lambermon, M. van IJzendoorn, Influencing mother - infant interaction through videotaped or written instruction: Evaluation of parent education programm, Early Childhood Research Quarterly, 1989, 4, s. 449-458.

${ }_{32} \mathrm{~J}$. Bowlby, Attachment and loss, Vol. 1 - Attachment; tenże, Attachment and loss, Vol. 2 - Separation; tenże, Attachment and loss, Vol. 2 - Loss: Sadness and depression; M.D.S. Ainsworth, Infancy in Uganda; M. Main, J. Solomon, Procedures of Identifying Infants as Disorganized, s. 121-161.

${ }_{33}$ Rodzicielska wrażliwość, zdaniem Ainsworth, polega na dostrzeżeniu sygnałów płynących od dziecka i reagowanie na nie w adekwatny sposób (M.D.S. Ainsworth, Infancy in Uganda; M.D.S. Ainsworth, S. Bell, D.D.J. Stayton, Individual differences in Strange Situation behaviour of one-year-olds, [w:] The origins of human relations, red. H.R. Schaffer, London 1971, s. 17-56).

${ }^{34}$ G. Kmita, Psychoterapia i niemowlęta, s. 348; por. F. Juffer, M.J. Bakermans-Kranenburg, M. van IJzendoorn, Promoting positive parenting.

${ }^{35}$ C. Werner, VIPP-SD Training Course, s. 14-15.

${ }^{36}$ Najczęściej są nimi matki (por. M. Gambin, Specyfika relacji dziecko-ojciec i jej znaczenie dla rozwoju dziecka z perspektywy zmian kulturowych przełomu XX i XXI wieku, [w:] W relacji. Studia z psychologii klinicznej dziecka 30 lat później, red. M. Święcicka, Warszawa 2018, s. 103-111; G. Kmita, Psychoterapia i niemowlęta, s. 340-399). 
rodzicielskiej wrażliwości. Stanowi zarazem odpowiedź na trudności, z jakimi często muszą mierzyć się rodzice dzieci powyżej pierwszego roku, które pojawiają się $\mathrm{w}$ czasie wprowadzania zasad istotnych podczas regulowania trudnych emocji dziecka oraz reakcji rodzica na jego zachowania problemowe. Należy bowiem mieć na uwadze, że więcej niż połowa dzieci w przedziale wiekowym od 16 do 36 miesięcy przejawia takie zachowania, jak: złość, nieposłuszeństwo, bicie, zły nastrój ${ }^{37}$. Duży wskaźnik zachowań eksternalizacyjnych u dzieci $\mathrm{w}$ okresie wczesnego dzieciństwa ${ }^{38}$ jest spowodowany gwałtownymi zmianami w rozwoju, które przejawiają się, między innymi, większą możliwością samodzielnego poruszania się oraz wzrostem potrzeby autonomii, które bardzo często napotykają przeszkodę w postaci rodzicielskich ograniczeńn ${ }^{39}$. Tacy badacze, jak Campbell, Ewing, Lavigne, Mesman, Stolk zauważają, że wysoki poziom przejawiania zachowań eksternalizacyjnych $\mathrm{w}$ okresie wczesnego dzieciństwa może być predyktorem zachowań antyspołecznych w późniejszym okresie życia ${ }^{40}$. Mając zatem na uwadze prawidłowy przebieg rozwoju osoby, badacze zalecają zwrócenie szczególnej uwagi na zachowania eksternalizacyjne pojawiające się u dziecka $w$ okresie wczesnego dzieciństwa ${ }^{41}$.

Ramą teoretyczną dla VIPP-SD są dwie teorie: teoria przywiązania ${ }^{42}$ oraz teoria przymusu (coercion theory) Geralda R. Pattersona ${ }^{43}$. Wywodzą się one, co prawda, z różnych orientacji teoretycznych, ale jak zauważa Shaw i Bell, w podejściu do zachowań eksternalizacyjnych małych dzieci uzupełniają się ${ }^{44}$. W ramach interwencji terapeutycznej VIPP, opartej na teorii przywiązania, dąży się do zastąpienia rodzicielskiej intruzywności, pojawiającej się w codziennych interakcjach z dzieckiem, rodzicielską wrażliwością. Natomiast, teoria przymusu daje rodzicom rozwiązania związane $\mathrm{z}$ wprowadzaniem dyscypliny rodzicielskiej, które nie wzmacniają negatywnego zachowania dziecka ${ }^{45}$. Patterson jest bowiem zdania, że zachowania problemowe u dzie-

${ }^{37} \mathrm{~J}$. Mesman i in., Extending the video-feedback intervention to sensitive discipline. The early prevention of antisocial behaviour, [w:] Promoting positive parenting. An attachment-based intervention, red. F. Juffer, M.J. Bakermans-Kranenburg, M. van IJzendoorn, New York - London 2008, s. 173.

${ }^{38}$ Mając na uwadze kryterium częstości występowania, są to zachowania normatywne, natomiast niepokój powinien budzić ich zakres i natężenie.

${ }^{39} \mathrm{~J}$. Mesman i in., Extending the video-feedback intervention to sensitive discipline, s. 173.

40 Tamże, s. 174.

${ }^{41}$ Tamże.

${ }^{42} \mathrm{~J}$. Bowlby, Attachment and loss, Vol. 1 - Attachment; tenże, Attachment and loss, Vol. 2 - Separation; tenże, Attachment and loss, Vol. 2 - Loss: Sadness and depression; M.D.S. Ainsworth, Infancy in Uganda; M. Main, J. Solomon, Procedures of Identifying Infants as Disorganized, s. 121-161.

${ }_{43}$ G.R. Patterson, Coercive family process, Castilia 1982; tenże, The early development of coercive family process, [w:] Antisocial behavior in in children and adolescents, red. J.B. Reid, G.R. Patterson, J. Snyder, Washington DC 2002, s. 25-44.

${ }^{44} \mathrm{~J}$. Mesman i in., Extending the video-feedback intervention to sensitive discipline, s. 177.

${ }^{45}$ Tamże, s. 176-177. 
ci, a więc takie, które z perspektywy rodziców/opiekunów stanowią źródło trudności wychowawczych, są efektem procesu wzmacniania przez nieświadomych konsekwencji swojego zachowania rodziców ${ }^{46}$.

Na krótkoterminową interwencję terapeutyczną VIPP-SD składa się siedem wizyt w domu rodzinnym dziecka. Konkretne wskazówki do prowadzenia terapii zawarte są w podręczniku: Manual VIPP-SD ${ }^{47}$. Za pomocą sprzętu wideo filmowane są interakcje, jakie zachodzą pomiędzy matką a dzieckiem w zwyczajnych sytuacjach domowych ${ }^{48}$ opisanych w podręczniku ${ }^{49}$. Czas filmowania każdej sytuacji jest krótki - od 3 do 6 minut ${ }^{50}$. Cechy procesu terapeutycznego realizowanego $\mathrm{w}$ ramach VIPP-SD są wspólne $\mathrm{z}$ innymi metodami terapeutycznymi skierowanymi do niemowląt/małych dzieci i ich rodziców ${ }^{51}$. Do najważniejszych należy mikroanaliza interakcji matka - dziecko, z koncentracją tylko na mocnych stronach dziecka i pozytywnych momentach interakcji pomiędzy dzieckiem a matką. Zatrzymany obraz wideo ${ }^{52}$, omawiany z matką, „jest oknem, przez które możemy zobaczyć, jak rodzina doświadcza siebie, dziecka, relacji”" ${ }^{3}$. Podczas mikroanalizy nagranego materiału uwzględniane jest podejście tu i teraz, co oznacza, że nie są analizowane doświadczenia z dzieciństwa matki. Natomiast, rodzic jest sam dla siebie modelem ${ }^{54} \mathrm{w}$ responsywnym byciu $\mathrm{z}$ dzieckiem.

Interwencja w ramach VIPP-SD ma doprowadzić do:

- wzrostu umiejętności obserwacji dziecka przez matkę;

- wiedzy dotyczącej rodzicielstwa i rozwoju małych dzieci;

- empatii i zrozumienia dziecka ${ }^{55}$.

Program interwencji składa się $z$ trzech faz. W fazie pierwszej (sesja pierwsza i druga) najważniejszym zadaniem jest nawiązanie pozytywnej relacji z matką przez osobę prowadzącą interwencję. Podczas tych sesji zwraca się uwage tylko na zachowanie dziecka oraz pozytywne sytuacje zachodzące w diadzie matka - dziecko ${ }^{56}$. Podczas fazy drugiej (sesja trzecia i czwarta)

${ }^{46}$ G.R. Patterson, Coercive family process; tenże, The early development of coercive family process, S. $25-44$.

${ }^{47}$ F. Juffer, M.J. Bakermans-Kranenburg, M. van IJzendoorn, Manual VIPP-SD.

48 Sytuacje: dziecko bawi się samo, dziecko bawi się z rodzicem, sprzątanie zabawek, wspólne przygotowanie posiłku, wspólne czytanie książki.

49 F. Juffer, M.J. Bakermans-Kranenburg, M. van IJzendoorn, Manual VIPP-SD.

${ }^{50}$ Wyjątkiem jest filmowanie przygotowania posiłku i jego spożywanie, które trwa do 30 minut.

51 G. Kmita, Psychoterapia i niemowlęta, s. 354.

52 W wypadku VIPP-SD interwał ten wynosi 10-30 sekund.

53 Za: G. Kmita G., Psychoterapia i niemowlęta, s. 352.

54 Pokazywanie matkom nagrania z modelem nie przyniosło pozytywnych rezultatów (por. M.E. Lambermoon, M. van IJzendoorn, Influencig mother - infant interaction through videotaped, s. 449-458).

55 J. Mesman i in., Extending the video-feedback intervention to sensitive discipline, s. 180.

56 Tamże. 
interwencja terapeutyczna ma na celu zmianę zachowania matki w stosunku do dziecka poprzez pokazywanie jej, jak skuteczny wpływ na funkcjonowanie dziecka ma pozytywne zachowanie rodzicielskie i w jaki sposób można je zastosować w różnych sytuacjach życia codziennego. W fazie trzeciej (sesja piąta, szósta i siódma) powtarzane są zadania z poprzednio przeprowadzonych sesji. W trakcie ich trwania należy zwracać uwagę na pozytywne interakcje między matką a dzieckiem. Ważne, aby matka zobaczyła swoje nowe kompetencje w byciu z dzieckiem, by poczuła, że jest „ekspertem” odnośnie własnego dziecka i bycia w relacji z nim ${ }^{57}$.

\section{VIPP-SD \\ a rodzice dzieci z grupy ryzyka rozwojowego}

Przedstawiony powyżej program VIPP-SD z założenia ma służyć minimalizowaniu ryzyka rozwojowego u dzieci, dotyczącego szerokiego spektrum zaburzeń. Jak wspomniano powyżej, w naukach psychologicznych i pedagogicznych istnieje zgoda co do znaczenia relacji przywiązaniowych dla przebiegu rozwoju dziecka. Już Bowlby ${ }^{58}$ podkreślał, że pozbawiona ciepła i wrażliwości rodzicielska relacja z dzieckiem wzmaga prawdopodobieństwo rozwoju psychopatologii ${ }^{59}$. W przypadku zagrożenia dotyczącego prawidłowości przebiegu procesów rozwojowych u dziecka, zastosowanie interwencji opartej na programie VIPP-SD z założenia ma prowadzić do uruchomienia zmiany zachodzącej w systemie rodzinnym, który stanowi podstawowy kontekst rozwoju dziecka. Podstawowy mechanizm zmiany opiera się na podniesieniu jakości rodzicielstwa, w szczególności wzroście wrażliwości i responsywności rodzicielskiej, co prowadzi do zmiany warunków, w których wychowuje się dziecko. Ma to szczególne znaczenie w rodzinach, w których istnieje ryzyko rozwojowe, co oznacza dla rodziców często konieczność zmagania się z negatywnymi emocjami, lękiem, smutkiem, niekiedy brakiem zaufania do własnych kompetencji rodzicielskich. W takiej sytuacji dostęp rodziców do ich wewnętrznych zasobów może być utrudniony, a wykorzystanie przez nich programów wsparcia jest szczególnie istotne.

Istotne jest wspomniane już fundamentalne założenie programu dotyczące odwoływania się w pracy do zasobów rodziny, co ma potencjał ich uwalniania, uruchamiania wewnętrznej siły rodziny, która w innym przypadku

57 Tamże.

58 J. Bowlby, The making and breaking of affectional bonds: etiology and psychopathology in the light of attachment theory, British Journal of Psychiatry, 1977, 130, s. 201-210.

59 Por. w: H. Kubiak, Relacja między adolescentami z zaburzeniami psychicznymi a ich rodzicami w świetle teorii przywiazania, [w:] Przywiąanie. Związki intymne, osobowość oraz problemy kliniczno-terapeutyczne, red. K. Lubiewska, Bydgoszcz 2017, s. 131-145. 
mogłaby zostać niezaktualizowana ${ }^{60}$. Ma to szczególne znaczenie w pracy z rodzinami stanowiącymi grupę ryzyka zaburzeń rozwojowych i/lub emocjonalnych oraz psychicznych u dzieci, ponieważ w sytuacji tej rodzice często przejawiają przekonanie o byciu niedostatecznie dobrymi rodzicami. Z tego przekonania mogą wynikać kolejne, na przykład dotyczące braku wystarczających kompetencji rodzicielskich, czy własnej niskiej sprawczości. Przekonania te wyznaczają poziom poczucia rodzicielskiej skuteczności (self-efficacy). Niski poziom tego poczucia jest powiązany z brakiem pewności w podejmowaniu działań wobec dziecka i znacząco wzmaga ryzyko rozwoju psychopatologii ${ }^{61}$.

Ryzyko rozwojowe u dzieci określano z zastosowaniem kryteriów związanych z:

- przebiegiem rozwoju dziecka (np. dzieci z zaburzeniami ze spektrum autyzmu $^{62}$, dzieci z niepełnosprawnością wzrokową ${ }^{63}$ i intelektualną ${ }^{64}$, dzieci z zaburzeniami eksternalizacyjnymi ${ }^{65}$ );

- funkcjonowaniem rodziców (np. rodzice z niepełnosprawnością intelektualną ${ }^{66}$ czy z zaburzeniami odżywiania ${ }^{67}$ );

- czynnikami rodzinnymi - środowiskowymi (np. rodziny o niskim statusie socjoekonomicznym, zagrożone maltretowaniem ${ }^{68}$, mniejszości etniczne $\left.{ }^{69}\right)$.

${ }^{60}$ H. Goldenberg, I. Goldenberg, Terapia rodzin, Kraków 2006.

${ }^{61}$ W. Oh, B. Volling, R. Gonzales, Trajectories of Children's Social Interactions With Their Infant Sibling in the First Year: A Multidimensional Approach, Journal of Family Psychology, 2015, 29(1), s. 119-129.

${ }^{62}$ I. Poslawsky i in., Development of a Video-feedback Intervention to promote Positive Parenting for Children with Autism (VIPP-AUTI), Attachment and Human Development, 2014, 16(4), s. 343-355.

${ }^{63}$ E. Broek i in., A Systematic Review of the Literature on Parenting of Young Children with Visual Impairments and the Adaptions for Video-Feedback Intervention to Promote Positive Parenting (VIPP), Journal of Developmental and Physical Disabilities, 2017, 29(3), s. 503-545.

${ }^{64}$ M.M. Overbeek i in., The effectiveness of VIPP-V parenting training for parents of young children with a visual or visual-and-intellectual disability: Study protocol of a multicenter randomized controlled trial, Trials, 2015, 16, s. 401.

${ }^{65}$ S. Yagmur i in., Video-feedback intervention increases sensitive parenting in ethnic minority mothers: a randomized control trial, Attachment and Human Development, 2014, 16(4), s. 371-386.

${ }^{66} \mathrm{M}$. Hodes i in., Effects of video-feedback intervention on harmonious parent-child interaction and sensitive discipline of parents with intellectual disabilities: A randomized controlled trial, Child: Care, Health and Development, 2018, 44(2), s. 304-311.

${ }^{67}$ A. Stein i in., Treating disturbances in the relationship between mothers with bulimic eating disorders and their infants: a randomized, controlled trial of video feedback, Journal of American Psychiatry, 2006, 163(5), s. 899-906.

${ }_{68}$ M. Negrao i in., Enhancing positive parents child interactions and family functioning in a poverty sample: a randomized control trial, Attachment and Human Development, 2014, 16, 4, s. 315-328.

${ }^{69}$ S. Yagmur i in., Video-feedback intervention increases sensitive parenting in ethnic minority mothers: a randomized control trial, Attachment and Human Development, 2014, 16(4), s. 371-386. 
Wspólną cechą wszystkich opisywanych sytuacji jest wyższe niż przeciętnie ryzyko zakłócenia płynności procesu: od sygnalizowania potrzeb przez dziecko, poprzez ich zaspokojenie przez rodziców, do uzyskania poczucia bezpieczeństwa i własnej istotności dziecka. Specyficzne sytuacje wiążą się z różnego rodzaju utrudnieniami dotyczącymi powyższego: na przykład $\mathrm{z}$ nietypowym sposobem komunikowania potrzeb przez dziecko, z deficytem wzmacniania rodziców kiedy odczytają potrzebę i zaspokoją ją (np. przez uśmiech czy inny sygnał potwierdzający relację), z brakiem gotowości i/lub umiejętności dorosłych dotyczących odczytywania i/lub zaspokojenia dziecięcych potrzeb. Zastosowanie programu VIPP-SD prowadzi również do określonych zmian w funkcjonowaniu rodzin; ich charakter jest częściowo niespecyficzny (wzrost rodzicielskiej wrażliwości i responsywności, spadek stresu rodzicielskiego), a częściowo specyficzny (np. wzrost autonomii dzieci w przypadku programu stosowanego w rodzinach wychowujących dzieci z niepełnosprawnością wzrokową i intelektualną czy spadek intruzywności matek w rodzinach, w których stosowana jest przemoc).

Poniżej przedstawiono pokrótce wybrane aspekty zastosowania VIPP-SD w niektórych grupach klinicznych.

Rodziny z dziećmi zagrożonymi nieprawidłowym przebiegiem rozwoju dziecka. Jak wskazano powyżej, VIPP-SD stosuje się w odniesieniu do rodzin wychowujących dzieci zagrożone niepełnosprawnością, zaburzeniami neurorozwojowymi czy psychicznymi. Stosunkowo wiele badań poświecono rodzicom i dzieciom z niepełnosprawnością wzrokową ${ }^{70}$ oraz sprzężoną; intelektualną oraz wzrokową ${ }^{71}$. W przypadku tych grup dzieci obserwuje się istotne odmienności $\mathrm{w}$ funkcjonowaniu $\mathrm{w}$ stosunku do dzieci prawidłowo rozwijających się, które mogą pozostawać w związku z procesem kształtowania się przywiązania między nimi a ich rodzicami. I tak, dzieci z niepełnosprawnością wzrokową sygnalizują swoje potrzeby w nietypowy sposób, co powoduje, że rodzice miewają znaczące trudności z ich odczytaniem. Dzieci nie są na przykład w stanie nawiązać kontaktu wzrokowego z rodzicami lub czynią to $\mathrm{w}$ ograniczonym zakresie, zatem opiekunowie pozbawieni są naturalnego wzmocnienia $\mathrm{w}$ procesach interakcji z dziećmi, a jeżeli nie nauczą się zastępować go w inny sposób, może to wpłynąć na ich poczucie pewności dotyczącej uczuć i zaangażowania dziecka. Podczas kontaktu wzrokowego z opiekunem, dzieci również upewniają się co do swego działania czy emocji - jeżeli ten sposób jest im niedostępny, dla prawidłowego przebiegu

${ }^{70}$ E. Broek i in., A Systematic Review of the Literature on Parenting of Young Children with Visual Impairments and the Adaptions for Video-Feedback Intervention to Promote Positive Parenting (VIPP), Journal of Developmental and Physical Disabilities, 2017, 29(3), s. 503-545.

${ }^{71}$ M.M. Overbeek i in., The effectiveness of VIPP-V parenting, s. 401. 
kształtowania relacji ze sobą samym, opiekunem i światem, dzieci potrzebują odmiennych dróg do osiągnięcia tych celów - i wypracowanie ich może być dla rodzin trudne. Co oczywiste, podczas uczenia się reagowania niewerbalnego, jednym z ważnych wykorzystywanych mechanizmów jest naśladowanie, utrudnione lub niemożliwe na podstawie informacji wzrokowych dla omawianych grup dzieci. Jeżeli konsekwencją tych trudności są nietypowe reakcje werbalne dzieci, to dalszym ich skutkiem mogą być kolejne problemy występujące po stronie rodziców, a dotyczące możliwości zrozumienia komunikatów płynących ze strony dziecka. Zakłócenie płynności komunikowania się wtórnie może zwiększać poziom stresu i u rodziców, i u dzieci ze wszelkimi tego konsekwencjami. Dzieci rodzą się ukierunkowane na kontakt z drugim człowiekiem, gotowe do podejmowania szeroko rozumianej komunikacji ${ }^{2}$. U dzieci z niepełnosprawnością wzrokową ta gotowość nie jest realizowana w sposób typowy, co może stać się przyczyną niepewności i zagubienia rodziców. Zaczynają oni skupiać się na negatywnych stronach interakcji, czują się odrzuceni przez dziecko, nierozumiejący i niezrozumiani ${ }^{73}$. Wtórnie - obniża to poczucie bezpieczeństwa u dziecka i wpływa na jego rozwój na wszystkich płaszczyznach. Z badań prowadzonych w tej szczególnej grupie ryzyka rozwojowego ${ }^{74}$ wynika, że program VIPP-SD sprzyja komunikowaniu się par dziecko - rodzic, wzmacnia wrażliwość rodzicielską, skłania ich do koncentracji na pozytywnych aspektach rodzicielstwa.

Przeprowadzono również szereg interesujących badań dotyczących zastosowania VIPP $w$ rodzinach wychowujących dzieci z problemami eksternalizacyjnymi i internalizacyjnymi. Takie problemy wskazują na wyższe niż w populacji ogólnej ryzyko wystąpienia u dzieci, obecnie lub w przyszłości, zaburzeń psychicznych. W kontekście coraz częstszego ich rozpoznawania ${ }^{75}$, bardzo istotne jest jak najwcześniejsze wdrażanie programów profilaktycznych i interwencyjnych.

$\mathrm{W}$ badaniach dotyczących skuteczności treningu stosowanego wobec rodzin wychowujących dzieci z zaburzeniami eksternalizacyjnymi podjęto próbę określenia nie tylko zakresu czy poziomu zmian, jakie zachodzą na skutek programu, ale też ich mechanizmów ${ }^{76}$. Ustalono, że związek pomię-

72 C. Trevarthen, Postawy intersubiektywności: rozwój rozumienia innych ludzi i rozumienia kooperacyjnego u małych dzieci, [w:] Psychologia języka dziecka, red. B. Bokus, G. Shugar, Gdańsk 2007, s. $101-123$.

${ }^{73}$ D. Howe, Disabled children, parent-child interaction and attachment, Children Family Social Work, 2006, 11, s. 95-06.

74 M.M. Overbeek i in., The effectiveness of VIPP-V parenting, s. 16 i 401.

75 P. Kendall, Terapia dzieci i młodzieży, Kraków 2010.

${ }_{76}$ M. Bakermans-Kranenburg i in., Experimental evidence for differential susceptibility: Dopamine D4 receptor polymorphism (DRD4 VNTR) moderates intervention effects on toddlers' externalizing behavior in a randomized controlled trial, Developmental Psychology, 2008, 44(1), s. 293-300. 
dzy czynnikami genetycznymi a oddziaływaniem środowiska odpowiada nie tylko za prezentowane przed podjęciem interwencji zachowania dzieci (np. te z kategorii eksternalizacyjnych), ale i za skuteczność programu, rozumianego na poziomie zmian $\mathrm{w}$ zachowaniu rodziców (przede wszystkim wzrost wrażliwości rodzicielskiej czy stosowanie tzw. pozytywnej dyscypliny) oraz dzieci (np. spadek częstości i natężenia zachowań eksternalizacyjnych). Powszechnie wiadomo, że czynniki środowiskowe wpływają na uruchomienie poszczególnych genów ${ }^{77}$, a zatem mają istotne znaczenie dla ekspresji potencjału zapisanego w genetycznym programie, a w omawianych badaniach potwierdzono, że specyfika uwarunkowań genetycznych (zwłaszcza związana z genem DRD4) ${ }^{78}$ różnicuje również odpowiedź uczestników na program VIPP. Ustalenia te nie znajdują na razie zastosowania w praktyce pedagogicznej czy psychologicznej, ale pomagają głębiej zrozumieć mechanizmy zachodzących zmian i być może w przyszłości staną się podstawą trafniejszego doboru interwencji do charakterystyki podlegających im osób.

Rodziny, w których czynnikiem ryzyka rozwojowego dla dzieci i relacji między nimi a opiekunami jest funkcjonowanie rodziców. Przeprowadzono również badania dotyczące skuteczności programu VIPP-SD w rodzinach, w których rodzice doświadczają niepełnosprawności intelektualnej ${ }^{79}$, matki zmagają się z zaburzeniami odżywiania, a szczegółowo z bulimią ${ }^{80}$.

Ta ostatnia sytuacja dotyczy około 4-5\% populacji i jest szczególnie złożona, ponieważ najczęściej bulimii towarzyszą objawy depresji. Zatem, matki są dotknięte złożonymi zaburzeniami, których objawy znajdują się zarówno w sferze emocji (smutek, złość, lęk), sferze myślenia (np. typowe błędy poznawcze, jak negatywna interpretacja, katastrofizowanie, pomniejszanie i wyolbrzymianie ${ }^{81}$ ), jak i zachowania (szerokie spektrum zachowań związanych z zaburzeniami, np. zwracanie pokarmu, czy używanie środków przeczyszczających, ale również unikanie ludzi). Wymienione objawy i związane z nimi cierpienie zazwyczaj powodują zmniejszenie poziomu wrażliwości ro-

77 Belsky mówi o hipotezie zróżnicowanej podatności (Belsky, za: G. Kmita, Co analiza w triadzie matka-ojciec-dziecko wnosi, s. 69-88). „Odnosi się ona do zróżnicowanej podatności na oddziaływania środowiska w zależności od posiadania określonych cech stanowiących »czynniki ryzyka«" za: tamże, s. 71.

78 Ciekawe są również wyniki badań Caspiego i jego zespołu nad genetycznymi (badano dwa warianty genu monoaminooksydazy-A) oraz środowiskowymi uwarunkowaniami agresji (za: za: G. Kmita, Co analiza w triadzie matka-ojciec-dziecko wnosi, s. 71).

79 M. Hodes i in., Effects of video-feedback intervention on harmonious parent-child, s. 304-311.

80 A. Stein i in., Treating disturbances in the relationship between mothers with bulimic eating disorders and their infants: a randomized, controlled trial of video feedback, Journal of American Psychiatry, 2006, 163(5), s. 899-906.

81 R. Leahy, Techniki terapii poznawczej, Kraków 2008. 
dzicielskiej ${ }^{82} \mathrm{w}$ wymiarze ogólnym i specyficznym, to jest dotyczącym dążenia dziecka do autonomii. Poza ogólnymi trudnościami u dzieci, stanowiącymi skutek deficytu doświadczenia własnej istotności i poczucia sprawstwa, jak ma to miejsce jeśli niemowlęta nie doświadczają wystarczająco szybkiej i trafnej odpowiedzi na sygnalizowane potrzeby, w tej szczególnej sytuacji u dzieci zazwyczaj występuje niższy poziom samodzielności, skoro nie są w tym obszarze wspierane przez matki.

Matki miewają też problemy z przyjmowaniem perspektywy dziecka większe niż w sytuacji, kiedy nie dotyczą ich zaburzenia odżywiania. W psy-

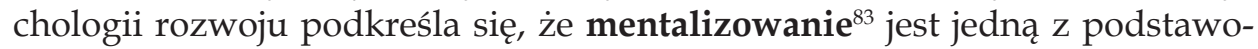
wych kompetencji wychowawczych, a jej deficyt wiąże się ze zwiększonym ryzykiem psychopatologii u dziecka ${ }^{84}$.

W rodzinach zaobserwowano również więcej, niż w innych, konfliktów $\mathrm{w}$ sytuacjach związanych $\mathrm{z}$ jedzeniem. Co istotne, w opisywanej sytuacji u dzieci stwierdza się niższą wagę niż w populacji dzieci matek bez zaburzeń odżywiania.

Trening VIPP-SD, jako ukierunkowany na wrażliwość rodzicielską i relację, zdaje się bardzo dobrze odpowiadać potrzebom tych rodzin. Rzeczywiście, w badaniach potwierdzono jego skuteczność ${ }^{85}$ : wzrost wrażliwości i responsywności rodzicielskiej, obniżenie poziomu stresu, znaczący spadek częstości konfliktów podczas posiłków, wzrost poziomu dziecięcej autonomii i wagi. Przykład ten jasno pokazuje, że skuteczność oddziaływań psychopedagogicznych wiąże się również z poprawą wskaźników zdrowia i rozwoju o charakterze somatycznym, w tym przypadku - wagą dzieci.

Środowisko rodzinne jako czynnik ryzyka rozwojowego u dzieci. Bywają sytuacje, kiedy niekorzystne oddziaływanie środowiska wykracza poza wymiar nieprawidłowego funkcjonowania rodzica - dotyczą całych rodzin i nierzadko są przekazywane z pokolenia na pokolenie. Badania prowadzono w rodzinach, w których stosowana bywa przemoc wobec dzieci; używa się przede wszystkim punitywnych metod wychowawczych, a statystycznie częściej niż w rodzinach bez tych problemów występuje niski status socjoekonomiczny, co wiąże się również z ograniczonymi możliwościami zaspokajania

82 A. Stein $\mathrm{i}$ in., Treating disturbances in the relationship between mothers with bulimic eating disorders, s. 899-906.

${ }^{83}$ Umiejętność odczytywania stanów umysłu innej osoby, w tym przypadku dziecka, opiera się na zdolności do przyjmowania innej perspektywy - mentalizowanie obejmuje m.in. tę kompetencję.

84 A. Slade i in., Maternal reflective functioning, attachment and the transmission gap, a preliminary study, Attachment and Human Development, 2005, 7(3), s. 283-298.

85 A. Stein i in., Treating disturbances in the relationship between mothers with bulimic eating disorders, s. 899-906. 
dziecięcych potrzeb związanych z leczeniem, edukacją, rozrywkami. Charakterystyka tych rodzin odpowiada opisowi rodzin ryzyka zaburzeń zachowania u dzieci i młodzieży ${ }^{86}$. Co szczególnie niepokojące, $\mathrm{w}$ rodzinach tych obserwuje się cykle agresji i lęku, duże ryzyko uzależnień, zarówno od substancji psychoaktywnych jak i behawioralnych, a ponieważ istnieje transmisja niekorzystnych wzorców emocji i zachowań między pokoleniami, dzieci stosunkowo często nie mogą liczyć ani na wsparcie rodziców, ani dziadków, którzy w innym przypadku mogliby przynajmniej częściowo zaspokajać potrzeby dzieci - tak dzieje się na przykład w sytuacji zaburzeń psychicznych $\mathrm{u}$ jednego $\mathrm{z}$ rodziców.

$\mathrm{W}$ badaniach ${ }^{87}$ stwierdzono, że zastosowany w opisywanych sytuacjach rodzinnych VIPP-SD jest skuteczny w obszarze wzrostu rodzicielskiej wrażliwości i responsywności oraz wysoce skuteczny w zmniejszaniu intruzywności rodziców - w konsekwencji rośnie samodzielność dzieci, częstość ich tak zwanych pozytywnych zachowań oraz poczucie pewności siebie. Spada poziom stresu u rodziców, rośnie spójność rodziny i poprawiają się wewnątrzrodzinne relacje. Zmienia się, na korzystniejszy, sposób dyscyplinowania dzieci - obniża się ryzyko stosowania wobec nich przemocy ${ }^{88}$. Ważnym i niepokojącym wnioskiem wywodzącym się z badań jest jednak związek skuteczności programu z płcią rodzica - matki rozwijają kompetencje rodzicielskie, a pozytywne efekty pracy dotyczą ich w stopniu o wiele większym niż ojców ${ }^{89}$.

Badania zdają się wskazywać, że zmiany w poziomie wrażliwości i responsywności u ojców nie występują lub są bardzo niewielkie i wtórne w stosunku do zmian zachodzących u kobiet. Oznacza to, że należy poszukać odmiennego niż dotąd sposobu dotarcia do ojców. Jedną z wartych wypróbowania metod oddziaływania mógłby być dialog motywujący ${ }^{90}$. Ta metoda pierwotnie została zaproponowana osobom borykającym się z uzależnienia$\mathrm{mi}$, nierzadko pozostającymi w trudnej sytuacji życiowej. Odpowiada ona trafnie na ich potrzeby, a jej skuteczność potwierdzono wobec osób stosujących przemoc $w$ rodzinie ${ }^{91}$. Możliwe zatem, że interwencja $w$ tej specyficznej sytuacji powinna być prowadzono dwuetapowo - w pierwszym, z wykorzy-

${ }^{86}$ Należy podkreślić, że $\mathrm{w}$ rodzinach tych problemy socjoekonomiczne są tylko jednym z czynników składających się na kontekst ryzyka. M. Seligman i in., Psychopatologia, Poznań 2001.

${ }^{87}$ M. Negrao i in., Enhancing positive parents child interactions and family functioning in a poverty sample: a randomized control trial, Attachment and Human Development, 2014, 16, 4, s. 315-328.

${ }^{88}$ I Pereira i in., $2014 \mathrm{w}$ : J. Cassidy, P. Shaver, Handbook of Attachment, Third Edition - Theory. Research and Clinical Applications, New York - London 2018.

${ }^{89}$ M. Negrao i in., Enhancing positive parents child interactions, s. 315-328.

${ }^{90}$ W. Miller, S. Rollnick, Wywiad motywujący, Kraków 2010.

${ }^{91} \mathrm{H}$. Woodin, Dialog motywujacy w terapii sprawców przemocy wobec partnera, [w:] Dialog motywujący w terapii problemów psychologicznych, red. H. Arkowitz, W. Mille, S. Rollnick, Kraków 2017, s. 373-399. 
staniem dialogu motywującego praca ukierunkowana byłaby na wzbudzenie motywacji do pracy, uwewnętrznienie jej celów, a dopiero drugi etap obejmowałby zastosowanie VIPP-SD jako promowanie pozytywnych aspektów rodzicielstwa, rozwijanie relacji z dzieckiem, poprawę atmosfery $w$ rodzinach.

Podsumowując, skuteczność zastosowania VIPPP-SD badano $\mathrm{w}$ bardzo wielu kontekstach w różnych krajach (Holandia, inne kraje Europy, także Wschodniej - np. Litwa), wobec zróżnicowanych grup (rodzice biologiczni, adopcyjni, opiekunowie w placówkach opiekuńczo-edukacyjnych i ich dzieci czy podopieczni), zróżnicowanych grup klinicznych, wobec rodzin o podwyższonym ryzyku rozwojowym - z punktu widzenia rozwoju dzieci, ale i rodziców. Wyniki tych badań potwierdzają skuteczność zastosowania programu, a przede wszystkim wzrost poziomu kompetencji rodzicielskich, szczególnie w obszarze wrażliwości i responsywności, rozwój wiedzy opiekunów na temat rozwoju dzieci, podwyższenie gotowości do dzielenia stanów dziecięcego umysłu przez osoby nimi się opiekujące, trafniejsze i bardziej wrażliwe stosowanie działań ukierunkowanych na dyscyplinowanie dzieci.

\section{BIBLIOGRAFIA}

Ainsworth M.D.S., Infancy in Uganda. Infant care and the growth of love, John Hopikns Press, Oxford 1967.

Ainsworth M.D.S., Bell S., Stayton D.D.J., Individual differences in Strange Situation behaviour of one-year-olds, [w:] The origins of human relations, red. H.R. Schaffer, Academic Press, London 1971.

Ainsworth M.D.S., Blehar M.C., Waters E., Wall S., Patterns of attachment. A psychological study of the Strange Situtation [Lawrence Erlbaum, Hillsdale, New York], Wydawnictwo Uniwersytetu Jagiellońskiego, Kraków 1978.

Bakermans-Kranenburg M., van IJzendoorn M., Pijlman M., Mesman J., Juffer F., Experimental evidence for differential susceptibility: Dopamine D4 receptor polymorphism (DRD4 VNTR) moderates intervention effects on toddlers' externalizing behavior in a randomized controlled trial, Developmental Psychology, 2008, 44(1).

Bowlby J., Attachment and loss, Vol. 1 - Attachment, Penguin Books, New York 1969.

Bowlby J., Attachment and loss, Vol. 2 - Separation, Penguin Books, New York 1973.

Bowlby J., Attachment and loss, Vol. 2 - Loss: Sadness and depression, Penguin Books, New York 1980.

Bowlby J., The making and breaking of affectional bonds: etiology and psychopathology in the light of attachment theory, British Journal of Psychiatry, 1977, 130.

Broek E., Eijden A., Overbeek M., Kef S., Sterkenburg P., Schuengel C., A Systematic Review of the Literature on Parenting of Young Children with Visual Impairments and the Adaptions for Video-Feedback Intervention to Promote Positive Parenting (VIPP), Journal of Developmental and Physical Disabilities, 2017, 29(3). 
Cassidy J., Emotion regulation: influences of attachment relationships, Monographs of the Society for Research in Child Development, red. N. Fox, 1994, 59(2-3).

Cassidy J., Shaver P., Handbook of Attachment, Third Edition - Theory. Research and Clinical Applications, The Guilford Press, New York - London 2018.

Dixon W., Twenty studies that revolutionized child psychology, wyd. 2, Saddle River, Pearson, New York 2016.

Gambin M., Specyfika relacji dziecko-ojciec i jej znaczenie dla rozwoju dziecka z perspektywy zmian kulturowych przełomu XX i XXI wieku, [w:] W relacji. Studia z psychologii klinicznej dziecka 30 lat później, red. M. Święcicka, Wydawnictwo Paradygmat, Warszawa 2018.

Goldenberg H., Goldenberg I., Terapia rodzin, Wydawnictwo Uniwersytetu Jagiellońskiego, Kraków 2006.

Górska D., Stawicka M., Mentalizacja w kontekście przywiąania, [w:] Mentalizacja z perspektywy rozwojowej i klinicznej, red. L. Cierpiałkowska, D. Górska, Wydawnictwo Naukowe UAM, Poznań 2016.

Hodes M., Meppelder M., de Moor M., Kef S., Schuengel C., Effects of video-feedback intervention on harmonious parent-child interaction and sensitive discipline of parents with intellectual disabilities: A randomized controlled trial, Child: Care, Health and Development, 2018, $44(2)$.

Howe D., Disabled children, parent-child interaction and attachment, Children Family Social Work, 2006, 11.

Juffer F., Bakermans-Kranenburg M.J., van IJzendoorn M., Disorganized infant attachment and preventive interventions: A review and meta-analysis, Infant Mental Health Journal, 2005, 26.

Juffer F., Bakermans-Kranenburg M.J., van IJzendoorn M., Promoting positive parenting. An attachment - based intervention, Lawrence Enbaun Associates, New York - London 2008.

Juffer F., Bakermans-Kranenburg M.J., van IJzendoorn M., Manual VIPP-SD. Video-feedback Intervention to promote Positive parenting and Sensitive Discipline, Centre for Child and Family Studies, Leiden University, Leiden 2015.

Juffer F, van IJzendoorn M., Bakermans-Kranenburg M.J., Less is more. Meta-analyses of sensitivity and attachment interventions in early childhood, Psychological Bulletin, 2003, 129.

Kendall P., Terapia dzieci i młodzieży, Wydawnictwo Uniwersytetu Jagiellońskiego, Kraków 2010.

Klein V., Juffer F., van IJzendoorn M., Bakermans-Kranenburg M.J., Effects of attachment-based interventions on maternal sensitivity and infant attachment: Differential susceptibility of highly reactive infants, Journal of Family Psychology, 2006, 20.

Kmita G., Psychoterapia i niemowlęta, [w:] Psychoterapia. Problemy pacjentów, red. L. Grzesiuk, H. Suszek, Wydawnictwo Eneteia, Warszawa 2011.

Kmita G., Co analiza w triadzie matka-ojciec-dziecko wnosi do rozumienia problemów dzieci zagrożonych zaburzeniami rozwoju i ich rodziców, [w:] W relacji. Studia z psychologii klinicznej dziecka 30 lat później, red. M. Święcicka, Wydawnictwo Paradygmat, Warszawa 2018.

Lambermon M.E., van IJzdendorn M.H., Influencig mother-infant interaction through videotaped or written instruction: Evaluation of parent education programm, Early Childhood Research Quarterly, 1989, 4.

Main M., Solomon J., Procedures of Identifying Infants as Disorganized/Disoriented during the Anisworth Strange Situation, [w:] Attachment in the preschool years: theory, research, and intervention, red. M.T. Greenberg, D. Cichetti, M. Cummings, University of Chicago Press, Chicago 1990.

Mesman J., Stolk M.N., van Zeij J., Alink L.R.A., Juffer F., Bakermans-Kranenburg M.J., van IJzendoorn M., Koot H.M., Extending the video-feedback intervention to sensitive discipline. 
The early prevention of antisocial behaviour, [w:] Promoting positive parenting. An attachment- based intervention, red. F. Juffer, M.J. Bakermans-Kranenburg, M. van IJzendoorn, Lawrence Enbaun Associates, New York - London 2008.

Miller W., Rollnick S., Wywiad motywujacy, Wydawnictwo Uniwersytetu Jagiellońskiego, Kraków 2010.

Patterson G.R., Coercive family process, Eugene, OR: Castilia 1982.

Patterson G.R., The early development of coercive family process, [w:] Antisocial behavior in in children and adolescents, red. J.B. Reid, G.R. Patterson, J. Snyder, American Psychological Association, Washington DC 2002.

Pisula E., Autyzm i przywiazanie. Studia nad interakcjami dzieci z autyzmem i ich matek, Gdańskie Wydawnictwo Psychologiczne, Gdańsk 2003.

Seligman M. i in., Psychopatologia, Wydawnictwo Zysk i S-ka, Poznań 2001.

Siegel D., Rozwój umystu. Jak stajemy się tym, kim jesteśmy, Wydawnictwo Uniwersytetu Jagiellońskiego, Kraków 2009.

Slade A., Grienenberger J., Bernbach E., Levy D., Locker A., Maternal reflective functioning, attachment and the transmission gap, a preliminary study, Attachment and Human Development, 2005, 7(3).

Sroufe A., Psychopathology as outcome of development, Development and Psychopathology, 1997, 9.

Stawicka M., Autodestruktywność dziecięca w świetle teorii przywiązania, Wydawnictwo Naukowe UAM, Poznań 2008.

Stein A., Woolley H., Senior R., Hertzmann L., Lovel M., Lee J., Cooper S., Wheatcroft R., Challacombe F., Patel P., Nicol-Harper R., Menzes P., Schmidt A., Juszczak E., Fairburn C., Treating disturbances in the relationship between mothers with bulimic eating disorders and their infants: a randomized, controlled trial of video feedback, Journal of American Psychiatry, 2006, 163(5).

Trevarthen C., Postawy intersubiektywności: rozwój rozumienia innych ludzi i rozumienia kooperacyjnego u matych dzieci, [w:] Psychologia jezzyka dziecka, red. B. Bokus, G. Shugar, Gdańskie Wydawnictwo Psychologiczne, Gdańsk 2007.

Werner C., VIPP-SD Training Course - niepublikowane materiały szkoleniowe z kursu VIPP-SD, 25-28.10., Bydgoszcz 2015.

Woodin H., Dialog motywujacy w terapii sprawców przemocy wobec partnera, [w:] Dialog motywujący w terapii problemów psychologicznych, red. H. Arkowitz, W. Mille, S. Rollnick, Wydawnictwo Uniwersytetu Jagiellońskiego, Kraków 2017.

Zalewska M., Dziecko i jego rodzice w kontakcie z psychologiem klinicznym, [w:] Problematyka kontaktu w diagnozie i terapii dzieci, red. M. Święcicka, M. Zalewska, Wydawnictwo EMU, Warszawa 2005.

Yagmur S., Mesman J., Malda M., Bakermans-Kranenburg M., Ekmekci H., Video-feedback intervention increases sensitive parenting in ethnic minority mothers: a randomized control trial, Attachment and Human Development, 2014, 16(4). 